\title{
Movement ecology of large herbivores in African savannas: current
}

\section{knowledge and gaps}

Norman OWEN-SMITH* Centre for African Ecology, School of Animal, Plant and Environmental Sciences, University of the Witwatersrand, Wits 2050, South Africa. E-mail: norman.owen-smith@wits.ac.za

Grant HOPCRAFT Institute of Biodiversity, Animal Health \& Comparative Medicine, University of Glasgow, Glasgow G12 8QQ, UK. E-mail: Grant.Hopcraft@glasgow.ac.uk

Thomas MORRISON Institute of Biodiversity, Animal Health \& Comparative Medicine, University of Glasgow, Glasgow G12 8QQ, UK. E-mail: Thomas.Morrison@glasgow.ac.uk

Simon CHAMAILLÉ-JAMMES CEFE, CNRS, Univ. Montpellier, Univ. Paul Valéry Montpellier 3, EPHE, IRD, Montpellier,

France. E-mail: simon.chamaille@cefe.cnrs.fr

Robyn HETEM School of Animal, Plant and Environmental Sciences, University of the Witwatersrand, Wits 2050, South

Africa. E-mail: robyn.hetem@wits.ac.za

Emily BENNITT Okavango Research Institute, University of Botswana, Maun, Botswana. E-mail: ebennitt@UB.AC.BW

Frank VAN LANGEVELDE Resource Ecology Group, Wageningen University, Wageningen, The Netherlands. E-mail:

frank.vanlangevelde@wur.nl 
*Correspondence author 


\section{ABSTRACT}

1. Nearly $90 \%$ of the world's large herbivore diversity occurs in Africa, yet there is a striking dearth of information on the movement ecology of these organisms compared to herbivores living in higher latitude ecosystems.

2. The environmental context for movements of large herbivores in African savanna ecosystems has several distinguishing features. African large herbivores move in landscapes with high spatiotemporal variability, low predictability, seasonal restrictions in surface water as well as food resources, and exposure to a diverse assemblage of competitors, predators and pathogens. These features influence mobility, diel activity routines, home range fidelity and exposure to predation.

3. We review the knowledge we have gained about the movements of African herbivores from GPS telemetry and identify important gaps in knowledge that exist. Topics addressed include seasonal movement patterns, daily activity schedules, space utilization, water dependency, responses to risks of predation, pathogen transmission, social affiliations and local population density determination.

4. While the growing number of GPS telemetry studies have addressed a wide range of topics in Africa, they remain fragmentary in terms of places and species represented. African landscapes are changing perhaps faster than any other region on Earth, with rapidly expanding human populations, massive infrastructure development projects and changes in climatic regimes. There is a crucial need to establish relationships between herbivore movements and their changing environments especially in Africa where most of the world's large herbivore diversity resides.

\section{Keywords}

Daily activity, home range, migration, predation, population dispersion 


\section{INTRODUCTION}

The advent of Global Positioning System (GPS) technology is enabling new insights into the ecology of animal movements (Kays et al. 2015). Studies on large herbivores using this technology have largely been concentrated on ungulates inhabiting northern temperate or arctic environments. Fewer studies have been conducted on large herbivores occupying African savanna environments. Yet, Africa houses $90 \%$ of the world's large herbivore diversity, and relatively intact populations of herbivores and carnivores -- a global heritage that is increasingly at risk (Ripple et al. 2016). Mounting threats include climate shifts in temperature and precipitation (Hetem et al. 2014) coupled with fences around reserves, roads and expanding human settlements and infrastructure (Ogutu et al. 2011, Fyumagwa et al. 2013). These developments prevent animals from moving as widely as they did in the past (Tucker et al. 2018, Veldhuis et al. 2019) and may even threaten the persistence of ecosystems (Løvschal et al. 2017).

African savannas are distinctive in several features. Environmental variation over space and through time is driven largely by fluctuations in rainfall, governing plant growth and surface water availability. Their tree and grass cover is modified locally by fire and herbivory (Sankaran et al. 2005). These savanna ecosystems uniquely retain a diverse mix of grazing, browsing and mixed feeding herbivores plus the large carnivores that feed on them.

In this review, we synthesize findings from recent research on the movements of African large herbivores based on GPS telemetry and identify gaps in knowledge needing to be addressed. Topics covered include seasonal movements over varying distances, activity schedules, space occupation at different scales, surface water dependency, thermoregulation, responses to predation risk, mechanisms of pathogen transmission and spatial limitations on abundance. We do not attempt inter-continental comparisons, nor do we cover the large amount of information gathered on the movements of African elephants. The large herbivores we have in mind are ungulates weighing over 10 $\mathrm{kg}$ in adult body mass. 


\section{WHAT DO WE KNOW AND STILL NOT KNOW?}

\section{When do seasonal movements represent migration?}

According to classic definitions, migration entails regular seasonal movements of animals between widely separated ranges (Avgar et al. 2014). Especially notable are coordinated mass shifts of populations between distant regions (Harris et al. 2009). But how far apart must these ranges be to qualify as migration (Cagnacci et al. 2016)? Movements that are less regularly expressed in time or space are better interpreted as nomadic (Teitelbaum \& Mueller 2019). Migrations may also be partial, with a variable portion of the population remaining behind after the migrants have moved away (Chapman et al. 2011). Is there any fundamental distinction between mass migrations and more local shifts between seasonal ranges?

What we know

Based on the published literature, as few as eight (Teitelbaum et al. 2015) or as many as 13 species (Harris et al. (2009) of African large herbivore have been regarded as having migratory populations. The archetypal migration by $\sim 1.3$ million wildebeest (Connochaetes taurinus) in the Serengeti region of Tanzania covers a linear distance of $210 \mathrm{~km}$, or round-trip circuit spanning $650 \mathrm{~km}$ (Thirgood et al. 2004, Hopcraft et al. 2015; Fig. 1A). This distance is coupled with a rainfall gradient from $550 \mathrm{~mm}$ between the south-eastern plains occupied during the wet season months to over 1000 $\mathrm{mm}$ in the northern Serengeti-Mara region inhabited during the dry season. Much smaller populations of wildebeest 
remain resident year-round within the western corridor, Ngorongoro highlands and Mara regions of the ecosystem. Nevertheless, GPS tracking has revealed how some of the supposedly resident animals show wide-ranging but opportunistic movements in response to prevailing conditions (Hopcraft unpublished; Fig. 1B).

Elsewhere in Tanzania, wildebeest have been tracked migrating over distances of 40-120 km from a dry season range in the vicinity of the Tarangire River to occupy either the Simanjiro Plains in the east or plains near Lake Natron in the north during the wet season (Morrison et al. 2012). In Kenya, wildebeest migrations from the Maasai Mara Reserve northward to the Loita Plains and from Nairobi National Park southward to the Athi-Kaputiei Plains have effectively collapsed due to human settlements, agriculture, roads and fencing (Ogutu et al. 2013, Stabach et al. 2016).

Within South Africa's Kruger National Park, wildebeest that had migrated $50 \mathrm{~km}$ seasonally towards surface water provided by a river to the south-west had this movement blocked by the completion of a fence along the western park boundary (Whyte \& Joubert 1988). Although the fence was removed in 1994, the migration has not been re-established. Nevertheless, some wildebeest fitted with GPS collars moved distances of $4-10 \mathrm{~km}$ between seasonally distinct home ranges, while other animals remained year-round within home ranges covering only a few square kilometres (Yoganand \& Owen-Smith 2014, Owen-Smith et al. 2015, Owen-Smith \& Traill 2017; Fig. 1C). Despite the vast difference in scale compared with the Serengeti migrants, the seasonal alternation in habitat conditions was basically similar: concentration in open regions with short grasses while sufficient green forage remained, followed by movement to places where some green grass was retained through the dry season along with perennial surface water.

The Kalahari area in southern Botswana formerly accommodated well over a hundred thousand wildebeest, until fences blocked their movement towards remaining water sources during a severe drought (Spinage \& Matlhare 1992). However, these seasonal movements were evidently nomadic, rather than regularly migratory (Verlinden 1998). One of the remaining wildebeest herds equipped with a GPS collar travelled a distance exceeding $200 \mathrm{~km}$ to seek water after surface water sources had dried up in its wet season range (Selebatso et al. 2018). 
The longest migration documented for any African ungulate is by white-eared kob (Kobus kob leucotis) in South Sudan (Fryxell \& Sinclair 1988, Schapira et al. 2017, Morjan et al. 2018). These animals are forced to move from the Boma region, where they congregate in the dry season, by rising floodwaters during the wet season. They shift to uplands in or near Bandigo National Park to the west, until the flood recedes sufficiently. Their seasonal movement spans a distance of up to $400 \mathrm{~km}$, with the round-trip circuit double this. Accompanying the 800,000 kob are 160,000 tiang (Damaliscus lunatus tiang) covering nearly the same distance, plus around 100,000 Mongalla gazelles (Eudorcas albonotata). Migratory populations of kob and tiang or topi have not been documented elsewhere, and movements of Thomson' gazelles (Eudorcas thomsoni) in Serengeti seem to be opportunistic rather than migratory (Fryxell et al. 2005).

Zebra (Equus quagga) family herds also migrate seasonally in the Serengeti ecosystem, but with a less coherent pattern than shown by wildebeest. While some collared zebra groups move with the wildebeest as far as the Mara region in Kenya, others relocate over shorter distances (Hopcraft, unpublished data). The longest migration for zebra is by animals moving between the Chobe River floodplain in north-east Namibia, occupied during the dry season, and Nxai Pan National Park in Botswana, where the animals remain for several weeks during the wet season -- a linear distance of $\sim 250 \mathrm{~km}$ (Naidoo et al. 2016). Other zebra herds within Botswana moved between a dry season range in the Okavango Delta and the Makgadikgadi Pan over a straight-line distance of 200 km (Bartlam-Brooks et al. 2011, 2013). These longdistance movements are newly established, or reinstated, because they would have been blocked by fences less than a decade ago. However, the majority of the zebra inhabiting the Okavango Delta region remain resident there year-round. Within the Makgadikgadi Pan National Park, approximately 15,000 zebra migrate $100 \mathrm{~km}$ from their dry season range on the Boteti River to a wet season range in short grassland to the east (Bradley 2012). Further north, several thousand zebra migrate from wet season ranges around the Mababe Depression to dry season ranges within the Linyanti floodplains (Sianga 2018). In Etosha National Park in Namibia, about 70\% of the zebra migrate over a distance of $60-80$ $\mathrm{km}$ to where numerous waterholes are available through the dry season while the remainder of the population remains 
within the wet season range year-round (Zidon et al. 2017). In contrast, zebras equipped with GPS collars in Kruger National Park remained within fixed but quite large home ranges year-round, apart from excursions to and from surface water during the dry season (Macandza et al. 2012a, Cain et al. 2012, Owen-Smith et al. 2015). Similarly sedentary movement patterns were exhibited by collared zebra in Hwange National Park (Chamaillé-Jammes, unpublished data).

African buffalo (Syncerus caffer) herds also exhibit a diversity of seasonal movement patterns. In northern Botswana and north-eastern Namibia, some herds moved over distances of up to $100 \mathrm{~km}$ between seasonally distinct home ranges, thus being labelled migratory (Naidoo et al. 2012b, Bennitt et al. 2016). Other buffalo herds in the same region, labelled 'expanders', traversed wider areas during the wet season overlapping with the range they occupied during the dry season. In W National Park in West Africa, collared buffalo herds remained close to rivers in the dry season but moved as far as $35 \mathrm{~km}$ away during the wet season (Cornelis et al. 2011). In northern Kruger National Park, collared buffalo shifted their home range occupation by merely $10 \mathrm{~km}$ to the vicinity of a seasonal river during the dry season (Macandza et al. 2012a). Where surface water is widely available, buffalo herds stayed in the same home range yearround, not only in Kruger National Park but also in Hwange and Gonarezhou national parks in Zimbabwe (N Owen-Smith, unpublished data, Chamailles-Jammes et al. submitted). Nevertheless, under severe drought conditions buffalo herds in Kruger National Park moved to distant areas that retained adequate forage (Staver, Wigley-Coetsee \& Botha 2019).

Although labelled as migratory (Harris et al. 2009), hartebeest (Alcelaphus buselaphus) and eland (Tragelaphus oryx) tracked by VHF telemetry in the Kalahari region of Botswana showed no seasonal regularity in their home range occupation (Verlinden 1988), and neither did eland in East Africa (Hillman 1988).

\section{Gaps in knowledge}

GPS tracking studies have revealed a diverse range of seasonal movement patterns, blurring the demarcation between 'genuine' migrations and more local shifts in seasonal home ranges. Can seasonal movements between home 
ranges a few kilometres apart, a distance that can be travelled within a few hours, justifiably be interpreted as migratory? All of the claimed migrants are grazers, constrained in the range extent they can occupy during the dry season by their surface water dependency. The Serengeti wildebeest abandon the south-eastern plains occupied during the wet season before all of this nutritious grass has been consumed, when remaining water becomes too saline (Gereta \& Wolanski 1998). Grazers less dependent on access to surface water, like various gazelles, show nomadic movements in search of green forage rather than being confined near surface water during the dry season (Fryxell et al. 2005). The fabled springbok treks of the past apparently represented opportunistic mass movements between summer and winter rainfall regions in search of food (Skinner 1993).

In the light of more detailed information on movement patterns available from GPS tracking, some qualifications are needed for the labels applied: short- versus long-distance migrants, partial versus mass migrations, and opportunistic versus regular seasonal range shifts. Exactly where these divisions should be placed requires more information on the seasonal movement patterns of individuals, populations and species. The particular gaps that need to be filled include (1) routes, timing and distribution of migratory or less regular movements, (2) trade-offs in benefits and costs between migratory and resident animals, and (3) understanding relationships between movement and resource availability, including water as well as food, plus exposure to predation.

\section{How are activities scheduled daily and seasonally?}

Savanna herbivores exhibit an activity routine entrained by the diel cycle of ambient temperature and illumination. Foraging typically predominates in the early morning and late afternoon, while resting prevails through midday and during much of the night (Owen-Smith 1998). Some feeding is necessary during the night in order to maintain digestive fermentation. High midday temperatures can restrict the time available for foraging during the day (Owen-Smith 1998, 
Fuller et al. 2016), as does time taken up by travel to and from remaining water sources in the dry season (Cain et al. 2012). Daily time spent foraging can be adjusted to compensate for reduced food availability to some extent, but at a cost in exposure to predation and heat stress. Both the scheduling and proportion of time devoted to foraging versus other activities may change seasonally, perhaps most crucially with regard to nocturnal activity.

\section{What we know}

GPS telemetry allows the movements of animals bearing collars to be documented throughout the day and night over complete annual cycles, generating vastly more information on movement patterns than can be obtained through direct observations. The challenge is to infer the activity states generating the movements. Because bouts of foraging and resting generally endure for 2-3 hours, intervals between successive GPS locations need to be hourly or less for activity states at this level of resolution to be recogised. For large herbivores, foraging activity generates a slow drift in location, while directed travel produces greater step displacements. Some fuzziness in activity state assignments is inevitable because of shifts in activity taking place during the intervals between successive GPS locations. Nevertheless, spells of resting can minimally be distinguished from more mobile activities (Patin et al. 2019), and directed travel from foraging or various minor activities generating slow movements (Owen-Smith et al. 2012).

GPS telemetry has been especially useful for revealing nocturnal activity patterns. In northern Kruger National Park, buffalo exhibited similar levels of activity through the day and night, while zebra and sable antelope (Hippotragus niger) were less active at night than during the day (Owen-Smith \& Goodall 2014; Fig. 2). Collared buffalos in Zimbabwe showed a similar activity pattern to the Kruger National Park animals (Valls-Fox et al. 2018). In the Schwelle region of Botswana, gemsbok (Oryx gazella), but not wildebeest, became proportionately more active at night during the hot dry season than during the cooler months (Boyers et al. 2019). These ungulates were all least mobile pre-dawn, indicating that this is the time when large herbivores sleep. Travelling becomes most prominent around dawn and dusk. Foraging 
activity typically shows peaks during the early morning and late afternoon, although some foraging evidently continues during the night (Owen-Smith \& Goodall 2014, Owen-Smith \& Traill 2017, Selebatso et al. 2017). In Kruger National Park, zebra devoted more time overall to foraging than did sable antelope or buffalo, in accordance with their non-ruminant digestion (Owen-Smith \& Goodall 2014). Sable antelope, but not zebra, foraged for longer per day towards the end of the dry season when food became sparse. In Mapungubwe National Park in northern South Africa, high ambient temperatures depressed the diurnal activity of wildebeest, eland and impala (Aepyceros melampus), particularly during summer (Shresta et al. 2014).

\section{Gaps in knowledge}

Studies inferring activity patterns from movements provide a baseline for comparisons among species, populations and conditions. More investigations are needed on how different ungulate species respond in their movements and activities to diel and seasonal variation in resources, thermal conditions, surface water availability and the threat of predation. How restricted is the time allocated to foraging activity while animals are migrating, or wandering nomadically in search of food, water or shade? Inferred activity states can be bolstered by accelerometers placed on or in animals to document fine-scale body movements (Tatler et al. 2018). Thermal loads influencing activity can be recorded using miniature black bulb thermometers attached to GPS collars, which combine the effects of radiant heat, ambient temperature and convective cooling (Hetem et al. 2007). Distinctions in the conditions selected for specific activities need to be established.

\section{How do herbivore species use space within home ranges?}


Spatial utilization patterns have widely been assessed in terms of within loosely bounded areas called home ranges (Spencer 2012). Kernel density estimators reveal relative intensities of use within home range limits. However, the places occupied for different activities are likely to vary, and change over the seasonal cycle, as influenced by patterns or resource renewal and depletion. Travelling to and from water may take animals well beyond the bounds of their usual home ranges. Over longer periods, animals adjust their space use in response to habitat changes, predator appearances or human intrusions.

\section{What we know}

Home ranges documented by GPS tracking overcome the sampling limitations of data obtained by VHF telemetry, being free of the constraints associated with human operators. They have revealed wide variation in how concentrated or expansive home range utilization can be among grazers with overlapping home ranges. Wildebeest herds in Kruger National Park concentrated their activities within open areas covering only a few square kilometres while sufficient grass remained. Zebra family units moved over a larger set of more diffuse patches, not only in Kruger National Park (OwenSmith \& Martin 2015, Owen-Smith et al. 2015), but also in the Makgadikgadi Pan region of Botswana (Brooks \& Harris 2008) and Hwange National Park in Zimbabwe (Chamaillé-Jammes unpublished). Similarly to wildebeest, sable antelope herds in Kruger National Park confined their foraging to fairly small patches, but favoured quite different habitat with taller grass and denser woody plant cover (Macandza et al. 2012a). The huge herds formed by buffalo move systematically over large home ranges, mostly separate from those of other buffalo herds (Owen-Smith, unpublished). Although the home ranges occupied by sable antelope herds overlapped spatially with those of buffalo herds, the sable restricted competitive overlap by avoiding areas recently grazed by the buffalo (Macandza et al. 2012b).

\section{Gaps in knowledge}


A reassessment of home range concepts is needed in the light of GPS data (Fiberg \& Borger 2012). For sedentary herbivores, more attention needs to be given to gaps representing unutilized patches within the home range extent, as well as areas not occupied by any home range. These gaps become evident only after GPS tracking has spanned a sufficient period. They need to be related to habitat features. For example, places no longer supporting sable antelope herds showed no differences in tree cover as revealed by LiDAR imagery from areas within occupied home ranges (Asner et al. 2015), suggesting that features of the grass cover must be more influential . Conditions leading animals to wander beyond their usual home ranges need to be identified, because opportunities for wider space use may be critical for survival during extreme conditions. For migratory animals, routes followed and staging areas occupied on route between seasonal home ranges need to be documented and related to prevailing circumstances.

Grazing rotations among sequences of exploited patches contribute to determining the overall home range extent needed by an individual animal or herd. An investigation of such patterns is needed especially for buffalo, because they are the archetypal large herbivores guiding rotational grazing principles for domestic livestock (Fynn 2012). Why do buffalo herds seldom over-graze, while domestic cattle commonly do so?

\section{How water-dependent are herbivores?}

Herbivore species differ in their physiological capacity to extract moisture during passage of food residues through the large intestine (Woodall \& Skinner 1993) and in their ability to concentrate urine (Maloiy et al. 1988). This influences their ability to survive without drinking water during the dry season. The frequency with which large grazers need to drink can form a major constraint on their spatial distribution and movements during dry times of the year (Gaylard et al. 2003). 


\section{What we know}

GPS tracking enables intervals between successive visits to water as well as ranging distances from water to be established. Sable antelope in northern Kruger National Park undertook journeys to pools remaining in a seasonal river every 3-4 days during the dry season, while zebra drank daily or every second day (Cain et al. 2012). The one-way distance travelled to water by sable antelope averaged 5-9 km, depending on the circumstances, while individual zebra herds travelled distances averaging from 3 to $8 \mathrm{~km}$. These journeys were undertaken during the latter part of the morning, and animals frequently remained in the vicinity of the water until conditions became cooler in the afternoon before embarking on the return journey back to their foraging areas. Thus the time lost for other activities in order to satisfy water requirements was greater than the travel time alone. Time available for foraging or resting was reduced by

$\sim 8$ hours for sable antelope and $\sim 5$ hours for zebra on the days when journeys to water occurred. In Hwange National Park, zebras similarly visited waterholes almost daily (Chamaillé-Jammes, unpublished data). In the Makgadikgadi Pan region of Botswana, wildebeest drank only every 2-4 days and grazed 10-15 km from a river (Curtin et al. 2018), and zebra went as long as 3-4 days between visits to water (Brooks et al. 2008). The basis for this unusual tolerance remains unclear.

Buffalo herds in Hwange National Park remained close to water through the dry season, and sometimes drank twice per day both in the early morning and at dusk (Valls-Fox et al. 2018). At the other extreme, gemsbok in the Kalahari region fitted with GPS collars rarely visited places where water was available, except during an extremely dry year (Boyers et al. 2019).

\section{Gaps in knowledge}

Much more information is needed to define the specific drinking requirements of various large herbivores under different conditions. Some browsers may go for prolonged periods without drinking, provided they can access sufficient 
green leaves. But under extremely dry conditions, even gemsbok and many browsers appear at waterholes. What are the thresholds in green forage availability controlling surface water dependence, and how do these differ among ungulate species? Further information is needed on how water quality influences the use of particular water sources.

The relative use of particular water sources also needs to be considered, comparing drinking at artificially maintained pools or troughs with visits to large dams and rivers. Wildlife managers frequently install additional water points to draw wildlife into unoccupied areas, but these seem to benefit the more common, water-dependent grazers (like zebra and buffalo) at the expense of less common species (like roan (Hippotragus equinus) and sable antelope: Harrington et al. 1999, Owen-Smith \& Mills 2006). More information is needed on how far animals move between foraging sites and places where they drink in order to provide guidance on the spacing of water sources (Owen-Smith 1996).

\section{How pervasive is the landscape of fear?}

It has been proposed that the 'landscape of fear' generated by the presence of predators strongly affects movements and habitat occupation by large herbivores (Laundre et al. 2010). Herbivores may reduce the risk of predation proactively, by occupying more secure habitats, being vigilant and by restricting their movements at times when carnivores are most active (Owen-Smith 2019). Space use patterns may be governed by habitat features that enhance the ability of animals to detect and escape from predators. Trade-offs between food acquisition and risks of predation are likely to exist between day and night, depending on whether the major predators hunt diurnally or nocturnally. Diminishing food resources during the dry season may force animals to forage in more risky habitats (Sinclair \& Arcese 1995). Prey responses may differ depending on whether the predators hunts by stalking or ambush versus prolonged pursuits (Thaker et al. 2011). Exposure to predation based on the frequency of encounters needs to be supported by 
assessments of the vulnerability of the prey to being killed contingent on the habitat conditions and time of day (OwenSmith 2015).

\section{What we know}

In Serengeti, collared wildebeest showed little response to risks associated with cover for stalking lions, perhaps gaining security from their aggregation in enormous herds (Hopcraft et al. 2014). Zebra moving in smaller herd units on the short-grass plains avoided situations where predation risk was high, but showed less response to spatial variation in risk while in woodlands. In central Kenya, zebra herds tended to occupy more densely wooded areas at night, despite the presence of lions (Fischhoff et al. 2007). In contrast, in Hwange National Park zebras remained in open localities during the night (Courbin et al. 2016, Davidson et al. 2012), and moved away from the waterholes where lions hunted (Courbin et al. 2019). In Kruger National Park, wildebeest confined their movements within the central regions of their diurnal foraging ranges during night, away from the edges where greater tree and grass cover could hide stalking lions (OwenSmith \& Traill 2017). In the Central Kalahari region of Botswana, collared wildebeest herds similarly remained in pan habitats with clear visibility during the night (Selebatso et al. 2017). Impalas shifted into more open areas at night from the more densely wooded areas that they occupy during the day (Riotte-Lambert et al. 2013).

Despite being highly apparent in the short grass lawns that they inhabited, wildebeest herds in west-central Kruger National Park did not encounter lions (Panthera leo) more frequently than did the more elusive zebra herds (Martin \& Owen-Smith 2016). Encounters with lions closer than $1 \mathrm{~km}$ occurred at mean intervals of 9 days for zebra and 7-8 days for wildebeest. Following encounters, wildebeest herds returned to the open patches where they typically resided, while zebra herds moved away from the vicinity of the contacts. In Hwange National Park, contacts between collared zebra herds and lions occurred at mean intervals of 35 days (Courbin et al. 2016). Most of the encounters took place $<1 \mathrm{~km}$ 
from water, and zebras tended to flee into more open areas several kilometres away following encounters (Courbin et al. 2016).

\section{Gaps in knowledge}

GPS telemetry opens new opportunities for documenting the topology of landscapes of fear based on the movement of predators, as well as how potential prey respond to the spatial threat. However, few studies in Africa have as yet deployed GPS collars on both predators and prey in the same region. The problem to be surmounted is dealing with multiple predators and prey species in the same area. Lions are the main threat for ungulates weighing over $100 \mathrm{~kg}$, but lions prey on a diverse suite of ungulates (Owen-Smith \& Mills 2008). Comparisons among species are also critical for understanding the non-consumptive effects of predation (Chamaillé-Jammes et al. 2019, Say-Sallaz et al. 2019).

Establishing the true frequency of encounters between predators and prey requires locations recorded more frequently than hourly, because much ground can be covered by both predator and prey during the dynamics of the interaction. Accelerometers could help document the specific movements of both interactors during a hunt, successful or otherwise (Wilson et al. 2018, Hetem et al 2019). Kills can be inferred from subsequent lack of movement by the predator provided that the carcass takes several hours to consume (Davidson et al. 2012). This would not be meaningful for spotted hyenas (Crocuta crocuta) or African wild dogs (Lycaon pictus), which typically devour carcasses within a few minutes.

\section{How do mobile herbivores transmit pathogens?}

The potential for wild ungulates to infect domestic livestock with pathogens depends on direct or indirect contacts affecting pathogen transmission. Buffalo are centrally involved as carriers for bovine tuberculosis as well as foot-and- 
mouth disease, both transmittable to cattle (Bengis et al. 2003). The fence along the western border of Kruger National Park was constructed mainly to restrict contacts between buffalo and cattle. In Botswana, veterinary cordon fences cross the country to separate wildlife areas from those given over to cattle ranching, largely to enable beef exports to Europe. Restrictions on wildlife movements can also increase the likelihood of infections becoming endemic within populations.

\section{What we know}

GPS telemetry has revealed that female buffalo dispersing between herds could spread pathogens over distances up to $100 \mathrm{~km}$ (Caron et al. 2016, Spaan et al. 2019). In Zimbabwe, contacts between buffalo and cattle take place mainly at waterholes on the periphery of protected areas during the dry season, where foot-and-mouth disease can potentially be transmitted to the livestock (Miguel et al. 2013). The mechanism for infection seems to be via the persistence of the virus in the soil rather than direct contacts between the wild and domestic ungulates (Miguel et al. 2017). In Etosha National Park in Zimbabwe, migratory zebra escaped infections with anthrax because the bacillus did not persist in the soil where these hosts were present only seasonally in the dry months (Zidon et al. 2017). Zebra that remained in the wet season range year-round were subject to continuing mortality from the disease.

\section{Gaps in knowledge}

Opportunities for investigating how wild herbivore movements affect pathogen transmission and contagion using GPS tags remain largely unexplored. Fences are being expanded throughout Africa without much understanding of how they will affect disease ecology. Fencing has wide implications for the establishment of Transfrontier Conservation Areas, which anticipate communities of people with cattle and other domestic livestock living alongside protected areas with 
abundant wildlife. Fences help by blocking incursions of livestock into protected areas, but at the cost of restricting wider movements by the wild herbivores. This is a blank area requiring further studies.

\section{How socially persistent are herds?}

Herd formation is a proactive response to the risk of predation, increasing vigilance and diluting the risk (Jarman 1974), as well as facilitating social interactions. Many African ungulates form quite small but cohesive herds that move as a unit within a shared home range; for example greater kudu (Tragelaphus strepsiceros; Owen-Smith 2013), sable antelope (Estes 1991, Hensman et al. 2014) and plains zebra (Klingel 1967), and even sedentary wildebeest (Owen-Smith \& Traill 2017). Herd members may, however, split and re-join over time. Female impala inhabit a common home range without necessarily moving together (Murrray 1982). Most male ungulates are associated only temporarily with breeding herds of females and young (Owen-Smith 1993). Herd members share a common pool of memory guiding their movements (Riotte-Lambert et al. 2015), supported by cultural transmission across generations (Jesmer et al. 2018).

\section{What we know}

GPS telemetry has revealed how ungulate herds can be open to transfers of animals between herd ranges as well as showing splitting and re-joining among herd members, most notably for buffalo (Winnie et al. 2008, Caron et al. 2016, Bennitt et al. 2018, Wielgus et al. submitted). Although the home ranges occupied by buffalo herds in Kruger National Park are largely discrete, individual females may disperse between the distinct herds (Spaan et al 2019). Dispersal movements tend to occur during times of resource stress such as the transition from the late dry season into the early wet season. 


\section{Gaps in knowledge}

Much more research is needed to establish how cohesive the herds formed by different ungulate species are, factors influencing their spacing and conditions promoting dispersal movements between herds. Multiple members of the same herds need to be tagged with GPS devices, or have proximity monitors placed, in order to establish relative frequencies of association among herd members (Torney et al. 2018).

Findings that sedentary ungulate herds comprising females and young may occupy largely discrete home ranges without overt defence need to be explored further, and underlying mechanisms (such as memory-driven foraging: Riotte-Lambert et al. 2015) investigated. Studies are also needed to show how independently males move relative to herds of females plus young. Additional devices such as animal-borne microphones (Wijers et al. 2019), cameras (Ossi et al. 2019) or proximity tags (Ossi et al. 2016) could help interpret social contexts. Long-term observations spanning multiple years are required to establish how persistent herd home ranges are.

\section{What limits population abundance?}

Animal movements and associations contributed towards determining locally effective population densities from the extent of the area actually occupied and the number of animals sharing this range (Borger 2016, Riotte-Lambert et al. 2017). Populations can grow in density both through increases in herd size and through expansions or contractions in the ranges covered or occupied by these herds (Chirima et al. 2012). The kinds of habitats they favour play a major role in governing local concentrations and gaps in use. When habitats deteriorate, animals must move over wider areas to secure their needs, perhaps leaving larger unutilized gaps 
within or between occupied ranges. Thus animal movements represent small-scale processes governing changes in population densities and distribution patterns, apart from the demography of births and deaths.

\section{What we know}

Spatial utilization patterns can help explain the huge contrast in regional abundance between wildebeest in Serengeti and wildebeest inhabiting Kruger National Park. The population density attained by migratory wildebeest in Serengeti (>50 individuals per $\mathrm{km}^{2}$ ) is more than 100 times the regional density exhibited by wildebeest in Kruger National Park $\left(<0.5\right.$ individuals per $\left.\mathrm{km}^{2}\right)$. Nevertheless, herds of 15-35 wildebeest in Kruger National Park remain within areas of 1.5-3 $\mathrm{km}^{2}$ for 6-10 months of the year (Yoganand et al. 2014), so that their locally effective density is almost 10 individuals per $\mathrm{km}^{2}$., much closer to the pressure on food resources within Serengeti. This suggests that the extent of sufficiently open habitat conferring security from predation, rather than solely contrasts in the nutritional value of food resources, contributes to governing the contrast in population abundance (Owen-Smith \& Traill 2017, Owen-Smith 2019).

\section{Gaps in knowledge}

Situations where ungulate herds occupy largely discrete home ranges open opportunities for investigating further how space utilization affects local population densities, and hence pressures on resources, in the context of predation and competition. The mechanisms enabling migratory populations to vastly exceed the abundance levels attained by resident populations also need to be established. Does this contrast arise from the effect of better nutrition in the wet season range on reproductive success? Might the reduced grazing pressure in the expanded dry season range support survival through this critical period of the year? Or is it a result of the alleviation of predation pressure as a consequence of population shifts beyond the ranges of settled predators? 


\section{OVERVIEW}

Much is being learnt about the movement patterns of certain large herbivores inhabiting African savannas from GPS telemetry, covering many aspects of ecology, as has been documented above. But studies have been restricted both in geographic coverage and in duration, and limited mainly to just three species. They inadequately represent the wide variation in movement patterns shown by different ungulate species, and by populations of the same species. Space occupation patterns range from settlement within small home ranges covering a few square kilometres to migratory shifts over thousands of square kilometres. Wide contrasts exist among species and local populations, and even within subpopulations. Space occupation patterns are contingent on environmental conditions and largely determine the regional and local density levels attained. There are suggestive indications that niche separation among these species is enabled largely by the spatial distinctions in their movements, related to security from predation as well as their food and water requirements.

How well these species cope with the strictures imposed by climate change and expanding human settlements with associated fencing and roads depends largely on how their movements are constrained. The crucial circumstances arise during extreme droughts or conditions where rains are unusually late, prompting animals to wander beyond their usual home ranges. If wider movements are blocked by fences or settlements, populations can crash dramatically.

Baseline documentation of movement patterns by large mammalian herbivories is urgently needed before the amplifications of global change restrict their movements even further. It is generally anticipated that species will show range shifts along temperature gradients in response to climate change (Parmesan \& Yohe 2003, Walther et al 2002). However, for savanna herbivores food production is controlled largely by rainfall, and forage quality depends on soil fertility. Exposure to predation is governed largely by the woody vegetation cover. Thus changes in habitat suitability independent of bioclimatic regimes need to be taken into account in projecting likely movement responses. A 
particularly insidious threat to savanna grazers lies in the bush thickening fuelled by elevated carbon dioxide levels in the atmosphere (Buitenwerf et al. 2012).

Large herbivores inhabiting African savanna environments pose an especially great challenge to research because of the diverse range of species represented and the influences of unpredictable rainfall on prevailing environmental conditions. Funding restricts the deployment of GPS collars to represent this heterogeneity, and sharing data is sorely needed to overcome this limitation in individual studies. A start has been made through the formation of the "AfriMove" network (http//afrimove.org), drawing from the Eurodeer/Euromammals experience (Cagnacci et al. 2011).

Once problems of restricted data availability have been overcome, the challenges of how best to analyse and interpret the data remain to be resolved. Seasonal movements tend to be less regular and more opportunistic when controlled by rainfall than in the temperature-driven seasons typical of higher northern latitudes. Daily activity routines get constrained within diel cycles of temperature and illumination. Places where food is secured during early morning and late afternoon foraging sessions may differ from the localities where animals are most secure from nocturnally active predators or effectively shaded from midday temperature extremes. Access to surface water may drive animals beyond their favoured habitats during dry season conditions. For grazers, habitat suitability depends both on the composition and structure of the grass layer providing food and on features of the woody vegetation cover affecting securing from predation. Prevailing fire regimes modify both.

Without more informed knowledge of the movement patterns of large herbivores in response to rapidly changing environments, we are likely to see a progressive loss of this legacy, as protected areas lose their effectiveness under shifts in climate, atmospheric $\mathrm{CO}_{2}$, and human activities plus infrastructure (Veldhuis et al. 2019). A far-sighted perspective is needed, conserving wildlife populations not only as a cultural heritage, but also as an essential resource for sustainable food production in increasingly hot and arid savannas. Africa's large mammal diversity constitutes both 
an unrivalled World Heritage and a valuable future resource, needing adequate resources marshalled internationally to ensure its persistence. Space use patterns documented in great detail by GPS telemetry are central to this endeavour.

\section{ACKNOWLEDGEMENTS}

This review was stimulated by a workshop held at the Wits Rural Facility in March 2018 to share data and collaborate in writing publications based on GPS data gathered for African large mammals. We acknowledge helpful suggestions for the manuscript provided by Melinda Boyers, Francesca Cagnacci, Victoria Goodall, Thomas Mueller, Francesca Parrini, Moses Selebatso and Maartin Strauss, and from the external reviewers.

\section{REFERENCES}

Asner GP, Owen-Smith N, Davies AB , Loarie SR, Le Roux E, Levick SR (2015) Habitat differences do not explain population declines of sable antelope in African savanna. Journal of Zoology 297: 225-234.

Avgar T, Street G, Fryxell JM (2014) On the adaptive benefits of mammal migration. Canadian Journal of Zoology 92: 481490. 
Bartlam-Brooks HLA, Bonyongo MC, Harris WS (2011) Will connecting ecosystems allow long-distance animal migrations to persist? A case study of a zebra migration in Botswana. Oryx 45: 210-216.

Bartlam-Brooks HLA, Beck PSA, Bohver G, Harris S (2013) In search of greener pastures: using satellite images to predict the effects of environmental change on zebra migrations. Journal of Geophysical Research: Biogeosciences 118: 1-11.

Bengis, RG, Kock RA, Fischer J (2002) Infectious animal diseases: the wildlife/livestock interface. In: Infectious Diseases of Wildlife: Detection, Diagnosis and Management. 53-65. O.I.E Scientific and Techmnical Review 21.

Bengis RG, Grant R, de Vos V (2003) Wildlife diseases and veterinary controls. In: du Toit JT, Rogers KH, Biggs HC (eds) The Kruger Experience. 349-369. Island Press, Washington DC.

Bennitt E, Bonyongo MC, Harris S (2016) Effects of divergent migratory strategies on access to resources for Cape buffalo. Journal of Mammalogy 97: 1682-1698.

Bennitt E, Bonyongo MC, Harris S (2018) Cape buffalo social dynamics in a flood-pulsed environment. Behavioral Ecology 29: 93-105.

Bennitt E, Hubel TY, Bartlam-Brooks HLA, Wilson AM (2019) Possible causes of divergent population trends in sympatric African herbivores. PLOS ONE 14(3): e0213720.

Berger-Tal O, Saltz D (2016) Indirect behavioural indicators and their uses in conservation and management. In: BergerTal O, Saltz D (eds) Conservation Behavior, 352-375. Cambridge University Press, Cambridge, UK.

Borger L (2016) Stuck in motion? Reconnecting questions and tools in movement ecology. Journal of Animal Ecology 85: 5-10. 
Boyers M (2019) How free-ranging ungulates with differing water dependencies cope with seasonal variation in temperature and aridity. Conservation Physiology 7: coz064.

Bradley J (2012) The effect of environmental variability on the foraging behaviour of plains zebra (Equus quagga) in the Makgadikgadi, Botswana. Ph.D., University of Bristol.

Brooks CJ, Harris S (2008) Directed movement and orientation across a large natural landscape by zebras. Animal Behaviour 76: 277-285.

Buitenwerf R, Bond WJ, Stevens N, Trollope WSW (2012) Increase tree densities in South African savannas: $>50$ years of data suggests $\mathrm{CO}_{2}$ as the driver. Global Change Biology 18: 675-684.

Cagnacci F, Focardi S, Heurich M, et al. (2011) Partial migration in roe deer: migratory and residency tactics are end points of a behavioural gradient determined by ecological factors. Oikos 120:1790-1802.

Cagnacci F, Focardi S, Ghisla A, van Moorter B, Merrill EH, Gurarie E et al. (2016) How many routes to migration? Comparison of methods to assess and characterize migratory movements. Journal of Animal Ecology 85: 54-68.

Cain JW, Owen-Smith N, Macandza V (2012) The costs of drinking: Comparative water dependency of sable antelope and zebra. Journal of Zoology 286:58-67.

Caron A, Cornelis D, Foggin C, Hofmeyr M, de Garine-Wichatitisky M. (2016) African buffalo movement and zoonotic disease risk across transfrontier conservation areas, southern Africa. Emerging Infectious Diseases 22: 277-280.

Chamaillé-Jammes S, Valeix M, Cromsigt J (2019) Predator Effects on Herbivore Dynamics and Behavior. What Mechanisms Lead to Trophic Cascades in Savannas? In: Scogings PF, Sankaran M (eds) Savanna Woody Plants and Large Herbivores'. John Wiley, Chichester, UK. 
Chapman B, Bronmark C, Nilsson JA, Hansson LA (2011) The ecology and evolution of partial migration. Oikos 120: 17641775.

Chirima JG, Owen-Smith N, Erasmus BNF. 2012. Recent distributions of larger ungulates in the Kruger National Park from ecological aerial survey data. Koedoe 54(1), Art. \#1009, 11 pages.

Cormelis D, Benhamou S, Janeau G, Morellet N, Ouedrago MN (2011) Spatiotemp[oral dynamics of forage and water resources shape space us of West African savanna buffalo. Journal of Mammalogy 92: 1287-1297.

Courbin N, Loveridge AJ, Macdonald DW, Fritz H, Valeix M, Makuwe ET, Chamaille-Jammes S (2016) Reactive responses of zebras to lion encounters shape their predator-prey space game at large scale. Oikos 125: 829-838.

Courbin N, Loveridge AJ, Fritz H, Macdonald DW, Patin R, Valeix M, Chamaillé-Jammes S (2019) Zebra diel migrations reduce encounter risk with lions at night. Journal of Animal Ecology 88: 92-101.

Curtin NA, Bartlam-Brooks HL, Hubel TY, Lowe JC, Gardner-Medwin AR, Bennitt E. et al. (2018). Remarkable muscles, remarkable locomotion in desert-dwelling wildebeest. Nature 563: 393.

Davidson Z, Valeix M, Loveridge AJ, Hunt JE, Johnson PJ, Madzikanda H, Macdonald DW (2012) Environmental determinants of habitat and kill site selection in a large carnivore: scale matters. Journal of Mammalogy 93: 677685.

Estes RD (1991) The Behavior Guide to African Mammals. University of California Press, Berkeley.

Fischhoff IR, Sundrasen SR, Cordingly J, Rubenstein DI (2007) Habitat use and movements of plains zebra in response to predation danger from lions. Behavioral Ecology 18: 725-729. 
Fryxell, JM, Sinclair ARE (1988) Seasonal migration by white-eared kob in relation to resoures. African Journal of Ecology 26: 17-31.

Fryxell JM, Wilmshurst JF, Sinclair ARE, Haydon DT, Holt RD, Abrams PA (2005) Landscape scale, heterogeneity, and the viability of Serengeti grazers. Ecology Letters 8:328-335.

Fuller, A, Mitchell, D, Maloney, SK \& Hetem, RS (2016). Towards a mechanistic understanding of the responses of large terrestrial mammals to heat and aridity associated with climate change. Climate Change Responses, 3, 10.

Fyumagwa R, Gereta E, Hassan S, Kideghesho JR, Kohi EM, Keyyu J et al. (2013) Roads as a threat to the Serengeti ecosystem. Biological Conservation 27: 1122-1125.

Fynn, RWS (2012) Functional resource heterogeneity increase livestock and rangeland productivity. Rangeland Ecology and Management 65: 319-329.

Gaylard A, Owen-Smith N, Redfern J (2003) Surface water availability: Implications for heterogeneity and ecosystem processes. In: du Toit JT, Rogers KH, Biggs HC (eds) The Kruger Experience, 171-188. Island Press, Washington DC.

Gereta E, Wolanski E (1998) Wildlife - water quality interaction in the Serengeti National Park. African Journal of Ecology 36: 1-14.

Harrington, R., N. Owen-Smith, P. Viljoen, H. Biggs \& D. Mason. 1999. Establishing the causes of the roan antelope decline in the Kruger National Park, South Africa. Biological Conservation 90:69-78

Harris G, Thirgood S, Hopcraft JGC, Cromsigt JPGM, Berger J (2009) Global decline in aggregated migrations of large terrestrial mammals. Endangered Species Research 7: 55-76. 
Hensman MC, Owen-Smith N, Parrini F, Bonyongo MC (2014) Home range occupation and habitat use of sable antelope in the Okavango Delta region of northern Botswana. African Journal of Ecology 52: 237-245.

Hetem RS, Maloney SK, Fuller A, Meyer LCR, Mitchell D (2007) Validation of a biometric technique, using ambulatory miniature black bulb thermometers to quantify thermoregulatory behaviour in ungulates. Journal of Experimental Zoology 307A: 342-356.

Hetem RS, Fuller A, Maloney SK, Mitchell D (2014) Responses of large mammals to climate change. Temperature 1: 115127.

Hetem RS, Maloney SK, Fuller A, Mitchell D (2016). Heterothermy in large mammals: inevitable or implemented? Biological Reviews 91, 187-205.

Hetem RS, Mitchell D, de Witt BA, Fick LG, Maloney SK, Meyer LC, Fuller A (2019). Body temperature, activity patterns, and hunting in free-living cheetah: biologging reveals new insights. Integrative Zoology 14: 30-47.

Hillman JC (1988) Home range and movement of the common eland in Kenya. African Journal of Ecology 26: 135-148.

Hopcraft JGC, Morales JM, Beyer HL, Borner M, Mwangomo E, Sinclair ARE, Olff H, Haydon DT (2014) Competition, predation, and migration: individual choice patterns of Serengeti migrants captured by hierarchical models. Ecological Monographs 84: 355-372.

Hopcraft JGC, Holdo RM, Mwangomo E, et al. (2015) Why are wildebeest the most abundant herbivore in the Serengeti ecosystem? In: Sinclair ARE, Metzger KL, Mduma SAR, Fryxell JM (eds) Serengeti IV, 125-174. University of Chicago Press, Chicago.

Jarman PJ (1974) The social organization of antelope in relation to their ecology. Behaviour 48: 215-267. 
Jesmer BR, Merkle JA, Goheen JR, Aikens EO, Beck JL, Courtemanch AB et al. (2018) Is ungulate migration culturally transmitted? Evidence of social learning from translocated animals. Science 361: 1023-1025

Kays R, Crofoot MC, Jetz W, Wikeski M (2015) Terrestrial animal tracking as an eye on life and planet. Science 348: aaa2478.

Klingel H (1967) Soziale organisation und Verhalten freilebender Steppenzebras. Zeitschrift fur Tierpsychologie 24: $580-$ 624.

Laundre JW, Hernandez L, Ripple WJ (2010) The landscape of fear: Ecological implications of being afraid. The Open Ecology Journal 2010, 3, 1-7.

Løvschal, M, Bøcher PK, Pilgaard J, Amoke I, Odingo A, Thuo A, Svenning J-C (2017). Fencing bodes a rapid collapse of the unique Greater Mara ecosystem. Scientific Reports, 7: 41450.

Macandza V, Owen-SmithN, Cain JW III (2012a) Habitat and resource partitioning between abundant and relatively rare grazing ungulates. Journal of Zoology 287: 175-185.

Macandza V, Owen-Smith N, Cain JW III (2012b) Dynamic spatial partitioning and coexistence among tall grass grazers in an African savanna. Oikos 121: 891-898.

Macandza V, Owen-Smith N, Le Roux E (2014) Faecal nutritional indicators in relation to the comparative population performance of sable antelope and other grazers. African Journal of Ecology 52: 300-307.

Maloiy GMO, Rugangazi BM, Clemens ET (1988) Physiology of the dik-dik antelope. Comparative Biochemistry and Physiology A 91: 1-8. 
Martin J, Benhamou S. Yoganand K, Owen-Smith N (2015) Coping with spatial heterogeneity and temporal variability in resources and risks: adaptive movement behaviour by a large grazing herbivore. PLOS ONE 10(2): e0118461.

Martin, J, Owen-Smith N (2016) Habitat selectivity influences the reactive responses of African ungulates to encounters with lions. Animal Behaviour 116:163-170.

Michelot T, Langrock R, Patterson TA (2016) moveHMM: an R package for the statistical modelling of animal movement

Miguel E, Grosbois V, Caron A, Boulinier T, Fritz H, Cornelis D, Foggin C, Makaya PV, Tshabalala PT, de Garine-Wichatitsky M (2013) Contacts and foot and mouth disease transmission from wild to domestic bovines in Africa. Ecosphere 4(4): $51,32 \mathrm{pp}$.

Miguel E, Grosbois V, Fritz H, Caron A, de Garine-Wichatitsky M, Nicod F, Loveridge AJ, Stapelkamp B, Macdonald DW, Valeix M (2017) Driers of foot-and-mouth disease in cattle at wild/domestic interface: insights from farmers, buffalo and lions. Diversity and Distributions 23: 1018-1030.

Morrison TA, Bolger DT (2012) Wet season range fidelity in a tropical migratory ungulate. Journal of Animal Ecology 81: 543-552.

Morjan MD, Rayl ND, Elkan PW, Deutsch JD, Henke MB, Fuller TK (2018) Armed conflict and development in South Sudan threatens some of Africa's longest and largest ungulate migrations. Biodiversity Conservation 27: 365-380.

Murray MG (1982) Home range, dispersal and the clan system of impala. African Journal of Ecology 20: 253-269.

Naidoo R, Du Preez P, Stuart-Hill G, Weaver LC, Jago M, Wegmann M (2012) Factors affecting intraspecific variation in home range size of a large African herbivore. Landscape Ecology 27: 1523-1534. 
Naidoo R, Du Preez P, Stuart-Hill G, Jago M, Wegmann M (2012) Home on the range: factors explaining partial migration of African buffalo in a tropical environment. PLOS ONE 7(5): e36527.

Naidoo R, Chase MJ, Beytell P, Du Preez P, Sanders K, Stuart-Hill G, Taylor R (2016) A newly discovered wildlife migration in Namibia and Botswana is the longest in Africa. Oryx 50: 138-146.

Newmark WD (2008) Isolation of African protected areas. Frontiers in Ecology and the Environment 6: 321-328.

Ogutu JO, Owen-Smith N, Piepho H-P, Said MY (2013) Continuing wildlife population declines and range contraction in the Mara region of Kenya during 1977-2009. Journal of Zoology 285: 99-109.

Ogutu JO, Owen-Smith N, Piepho H-P, Said MY, Kifugo S, Reid RS. 2013. Changing wildlife populations in Nairobi National Park and adjoining Athi-Kaputiei Plains: collapse of the migratory wildebeest. The Open Conservation Biology Journal 7: 11-26.

Ossi F, Focardi S, Picco GP, Murphy A, Molteni D, Tolhurst B, Giannini N, Gaillard JM Cagnacci F (2016) Understanding and geo-referencing animal contacts: proximity sensor networks integrated with GPS-based telemetry. Animal Biotelemetry, 4(1), p.21.

Ossi F, Urbano F, Cagnacci F (2019). Biologging and Remote-Sensing of Behavior. In: Choe, J.C. (Ed.), Encyclopedia of Animal Behavior, (2nd ed.). vol. 3, pp. 429-446. Elsevier, Academic Press.

Owen-Smith N (1993) Age, size, dominance and reproduction among male kudus: mating enhancement by attrition of rivals. Behavioral Ecology and Sociobiology 32: 177-184.

Owen-Smith N (1996) Ecological guidelines for waterpoints in extensive protected areas. South African Journal of Wildlife Research 26: 107-112. 
Owen-Smith N (1998) How high ambient temperature affects the daily activity and foraging time of a subtropical ungulate, the greater kudu. Journal of Zoology, London 246:183-192.

Owen-Smith N (2002) Adaptive Herbivore Ecology. From Resources to Populations in Variable Environments. Cambridge University Press, Cambridge UK.

Owen-Smith N (2006) Demographic determination of the shape of density dependence for three African ungulate populations. Ecological Monographs 76:73-92.

Owen-Smith N (2013.) Tragelaphus strepsiceros Greater Kudu. In: Kingdon JS, Hoffmann M (eds) The Mammals of Africa Vol. VI. Pigs, Hippopotamuses, Chevrotain, Giraffes, Deer and Bovids, 152-159. Bloomsbury, London.

Owen-Smith N (2015) How diverse large herbivores coexist with multiple large carnivores in African savanna ecosystems: demographic, temporal and spatial influences on prey vulnerability. Oikos 124: 1417-1426.

Owen-Smith N (2019) Ramifying effects of the risk of predation on African multi-predator, multi-prey large-mammal assemblages and the conservation implications. Biological Conservation 232:51-58.

Owen-Smith N, Goodall V (2014) Coping with savanna seasonality: comparative daily activity patterns of African ungulates as revealed by GPS telemetry. Journal of Zoology 293: 181-191.

Owen-Smith N, Goodall V, Fatti LP (2012) Applying mixture models to derive activity states of large herbivores from movement rates inferred using GPS telemetry. Wildlife Research 39: 452-462.

Owen-Smith N, Martin J (2015) Identifying space use at foraging arena scale within the home ranges of large herbivores. PIOS ONE 10(6):e0128821, 21pp 
Owen-Smith N, Martin J. Yoganand K (2015) Spatially nested niche partitioning between syntopic grazers at foraging arena scale within overlapping home ranges. Ecosphere 6(9):152, 17pp.

Owen-Smith N, Mills MGL (2008) Predator-prey size relationships in an African large-mammal food-web. Journal of Animal Ecology 77: 173-183.

Owen-Smith N, Traill L (2017) Space use patterns of a large mammalian herbivore distinguished by activity state: fear versus food? Journal of Zoology 303: 281-290.

Parmesan C, Yohe G. (2003) A globally coherent fingerprint of climate change impacts across natural systems. Nature 421: 37-42.

Patin R, Etienne MP, Lebarbier E, Chamaillé-Jammes S, Benhamou S (2019) Identifying stationary phases in multivariate time-series for highlighting behavioural modes and home range settlements. Journal of Animal Ecology, Early view.

Riotte-Lambert L, Benhamou S, Chamaillé-Jammes S (2013) Periodicity analysis of movement recursions. Journal of Theoretical Biology 317: 238-243.

Riotte-Lambert L, Benhamou S, Chamaille-Jammes S (2015) How memory-based movement leads to non-territorial spatial segregation. American Naturalist 185: E103-E116.

Riotte-Lambert L, Benhamou S, Bonenfant C, Chamaille-Jammes S (2017) Spatial memory shapes density dependence and population dynamics. Proceedings of the Royal Society 284: 20071411.

Ripple WJ (2016) Saving the world's terrestrial megafauna. Bioscience 66: 807-812. 
Sankaran M, Hanan MP, Scholes RJ (2005) Determinants of woody cover in African savannas. Nature 438:846-849.

Say-Sallaz E, Chamaillé-Jammes S, Fritz H, Valeix M (2019) Non-consumptive effects of predation in large terrestrial mammals: Mapping our knowledge and revealing the tip of the iceberg. Biological Conservation 235: 36-52.

Schapira P, Monica M, Rolkier G, Bauer H (2017) Wildlife migration in Ethiopia and South Sudan longer than " the longest in Africa": a response to Naidoo et al. Oryx 51: 19.

Sianga K (2018) Vegetation heterogeneity and its effects on large herbivores in the Savuti-Mababe-Linyanti ecosystem, northern Botswana. Ph.D., University of Botswana.

Selebatso M, Fynn R, Maude G (2017) Adaptive activity patterns of a blue wildebeest population to environmental variability in fragmented, semi-arid Kalahari, Botswana. Journal of Arid Environments 136: 15-18.

Selebatso M, Bennitt E, Maude G, Fynn RWS (2018) Water provision alters wildebeest adaptive habitat selection and resilience in Central Kalahari. African Journal of Ecology 56: 225-234.

Settele J, Scholes R, Betts J, Bunn S, Leadley P,Nepstad D (2014) Terrestrial and inland water systems. In: Field CB et al. (eds) Climate Change 2014: Impacts, Adaptation, and Vulnerability. Part A: Global and Sectoral Aspects.

Contribution of Working Group II to the Fifth Assessment Report of the Intergovernmental Panel on Climate Change 271-359. Cambridge University Press, Cambridge, UK

Shrestha A.K., S.E. van Wieren, F. van Langevelde, A. Fuller, R.S. Hetem, L.C.R. Meyer, S. de Bie and H.H.T. Prins (2014) Larger antelopes are sensitive to heat stress throughout all seasons but smaller antelope only during summer in an African semi-arid environment. International Journal of Biometeorology 58:41-49 
Sinclair ARE, Arcese P (1995) Population consequences of predation-sensitive foraging: The Serengeti wildebeest. Ecology 76: 882-891.

Skinner JD (1993) Springbok treks. Transactions of the Royal Society of South Africa 48: 291-305.

Spaan RS, Epps CW, Ezenwa VO, Jolles AE. (2019) Why did the buffalo cross the park? Resource shortages but not infections drive dispersal in female African buffalo. Ecology and Evolution in press.

Spencer WD (2012) Home ranges and the value of spatial information. Journal of Mammalogy 93: 929-947.

Spinage CA, Matlhare JM (1992) Is the Kalahari cornucopia fact or fiction? A predictive model. Journal of Applied Ecology 29: 605-610.

Stabach JA, Wittemyer G, Boone RB, Reid RS, Worden JS (2016) Variation in habitat selection by white-bearded wildebeest across different degrees of human disturbance. Ecosphere 7(8): e01428.

Staver AC, Wigley-Coetsee C, Botha J (2019) Grazer movements exacerbate grass declines during drought in an African savanna. Journal of Ecology 107: 1482-1491.

Tatler J et al. 2018. High accuracy at low frequency: detailed behavioural classification from accelerometer data. Journal of Experimental Biology 221.23 jeb184085.

Teitelbaum CS, Fagan WF, Flemming CH, Dressler G, Calabrese JM, Leimgruber P, Mueller T (2015) How far to go? Determinants of migration distance in land mammals. Ecology Letters 18: 545-552.

Teitelbaum CS, Mueller T (2019) Beyond migration: Causes and consequences of nomadic animal movements. Trends in Ecology and Evolution 
Thaker M, Vanak AT, Owen CR, Ogden MB, Niemann SM, Slotow R (2011) Minimizing predation risk in a landscape of multiple predators: effects on the spatial distribution of African ungulates. Ecology 92: 398-407.

Thirgood S, Mosser A, Tham S, Hopcraft G, Mwangomo E, Mlengeya T, Kilewo M, Fryxell J, Sinclair ARE, Borner M (2004) Can parks protect migratory ungulates? The case of the Serengeti wildebeest. Animal Conservation 7: 113-120.

Torney CJ, Hopcraft JGC, Morrison TA, Couzin ID, Levin SA (2018) From single steps to mass migration: the problem of scale in the movement ecology of the Serengeti wildebeest. Philosophical Transactions of the Royal Society B 373: 20170012.

Tucker MA, Bohring-Gaese K, Fagen WF, Fryxell JM, van Moorter B, Alberts SC (2018). Moving in the Anthropocene: Global reductions in terrestrial mammalian movements. Science 359: 466-469.

Valls-Fox H, Chamaille-Jammes S, de Garine-Wichatitsky M, Perrotton A (2018) Water and cattle shape habitat selection by wild herbivores at the edge of a protected area. Animal Conservation 21: 365-375.

Veldhuis MP, Ritchie ME, Ogutu JO, Morrison TA, Beale CM, Estes AB et al. (2019) The Serengeti Squeeze: crossboundary human impacts compromise an iconic protected ecosystem. Science. 363: 1424-1428.

Verlinden A (1998) Seasonal movement patterns of some ungulates in the Kalahari ecosystem of Botswana between 1990 and 1995. African Journal of Ecology 36: 117-128.

Walther G-R, Post E, Convey P, Menzel A, Parmesan C, Beebee TJC et al. (2002) Ecological responses to recent climate change. Nature 416: 389-395.

Whyte IJ, Joubert SCJ (1988) Blue wildebeest population trends in the Kruger National-Park and the effects of fencing. South African Journal of Wildlife Research 18:78-87. 
Wijers M, Trethowan P, Markham A, du Preez B, Chamaillé-Jammes S, Loveridge AW, Macdonald DW (2019) Listening to lions: Animal-borne acoustic sensors improve bio-logger calibration and behaviour classification performance. Frontiers in Ecology and Evolution https://doi.org/10.3389/fevo.2018.00171

Wilson AM, Hubel TY, Wilshin SD, Lowe JC, Lorenc M, Dewhirst OP et al. (2018) Biomechanics of predator-prey arms race in lion, zebra, cheetah and impala. Nature 554:183-188.

Winnie JA, Cross P, Getz W (2008) Habitat quality and heterogeneity influence distribution and behaviour in African buffalo. Ecology 89: 1457-1468.

Woodall PF, Skinner JD (1993) Dimensions of the intestine, diet and faecal water loss in some African antelope. Journal of Zoology 229:457-471.

Yiu S-W, Owen-Smith N, Cain JW (submitted) How do lions move when they hunt? Animal Behaviour

Yoganand, K. \& N. Owen-Smith. 2014. Restricted habitat use by an African savanna herbivore through the seasonal cycle: key resources concept expanded. Ecography 37:969-982.

Zidon R, Garti S, Getz WM, Saltz D (2017) Zebra migration strategies and anthrax in Etosha National Park, Namibia. Ecosphere 8(8): e01925. 
FIGURES

Figure 1 Seasonal patterns of space occupation comparing (A) migratory wildebeest in Serengeti, (B) resident wildebeest in western Serengeti, and $(C)$ resident wildebeest in Kruger National Park. Note the differing grid scales. For A and B green is early wet season, blue late wet season and grey dry season. For C green represents wet and early dry seasons, grey late dry season.
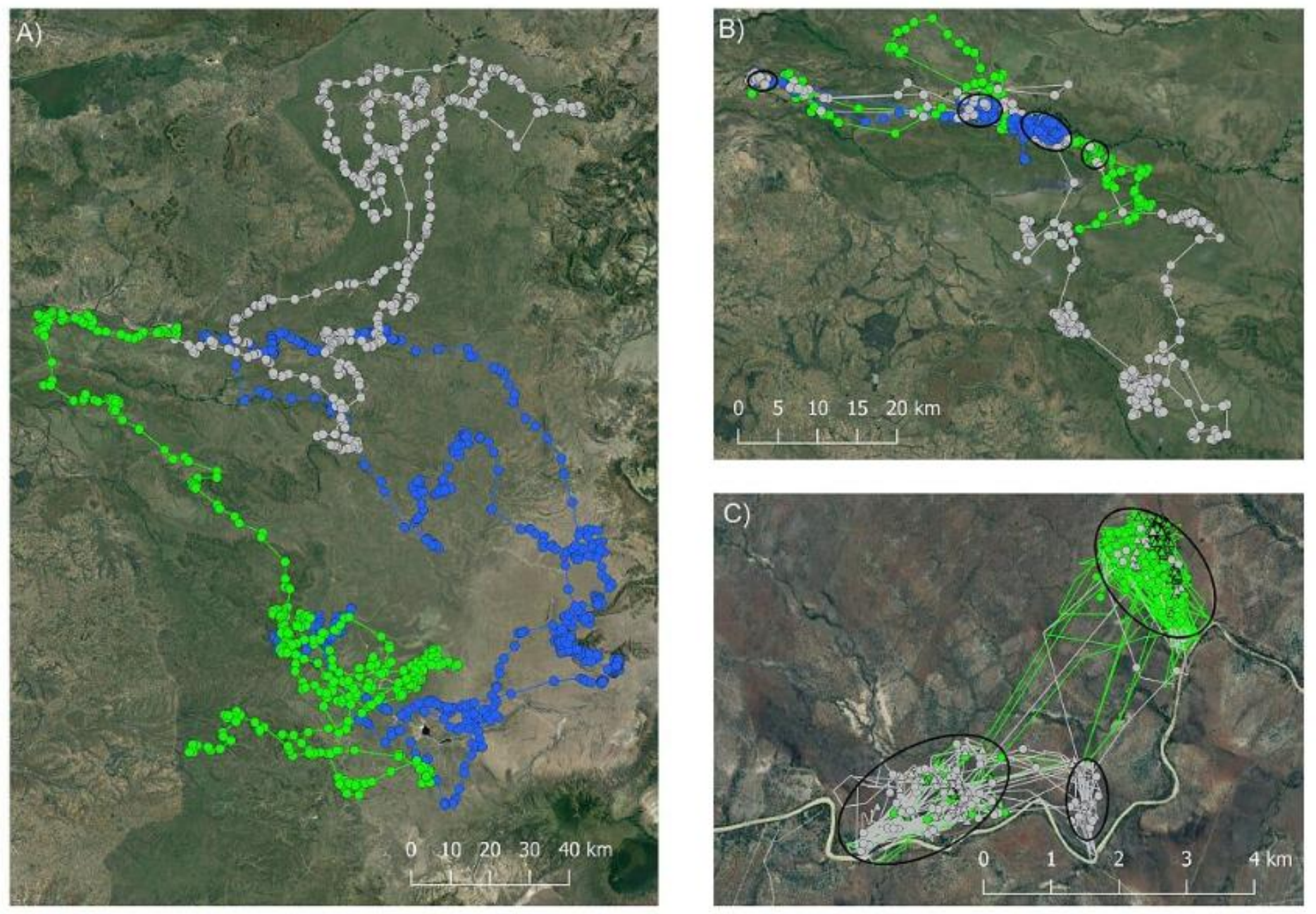
Figure 2 Translating hourly movement rates into activity states for wildebeest, zebra and buffalo herds in Kruger National Park fitted with GPS collars by fitting independent mixture models. For zebra and buffalo, activity has been apportioned among the three basic activities. For wildebeest, mixed movement has been retained as a distinctive state.
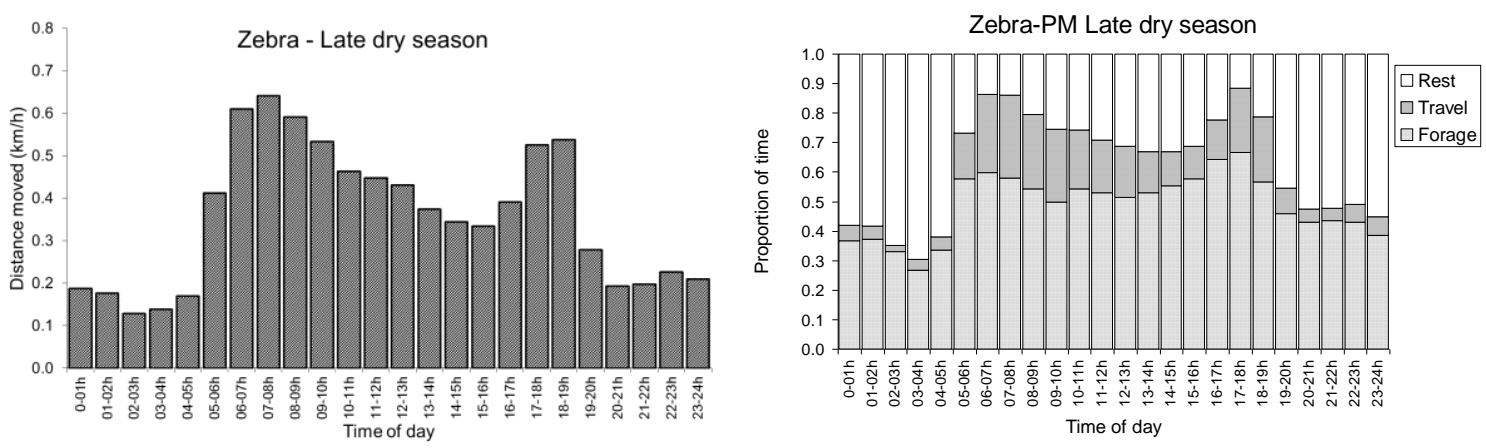

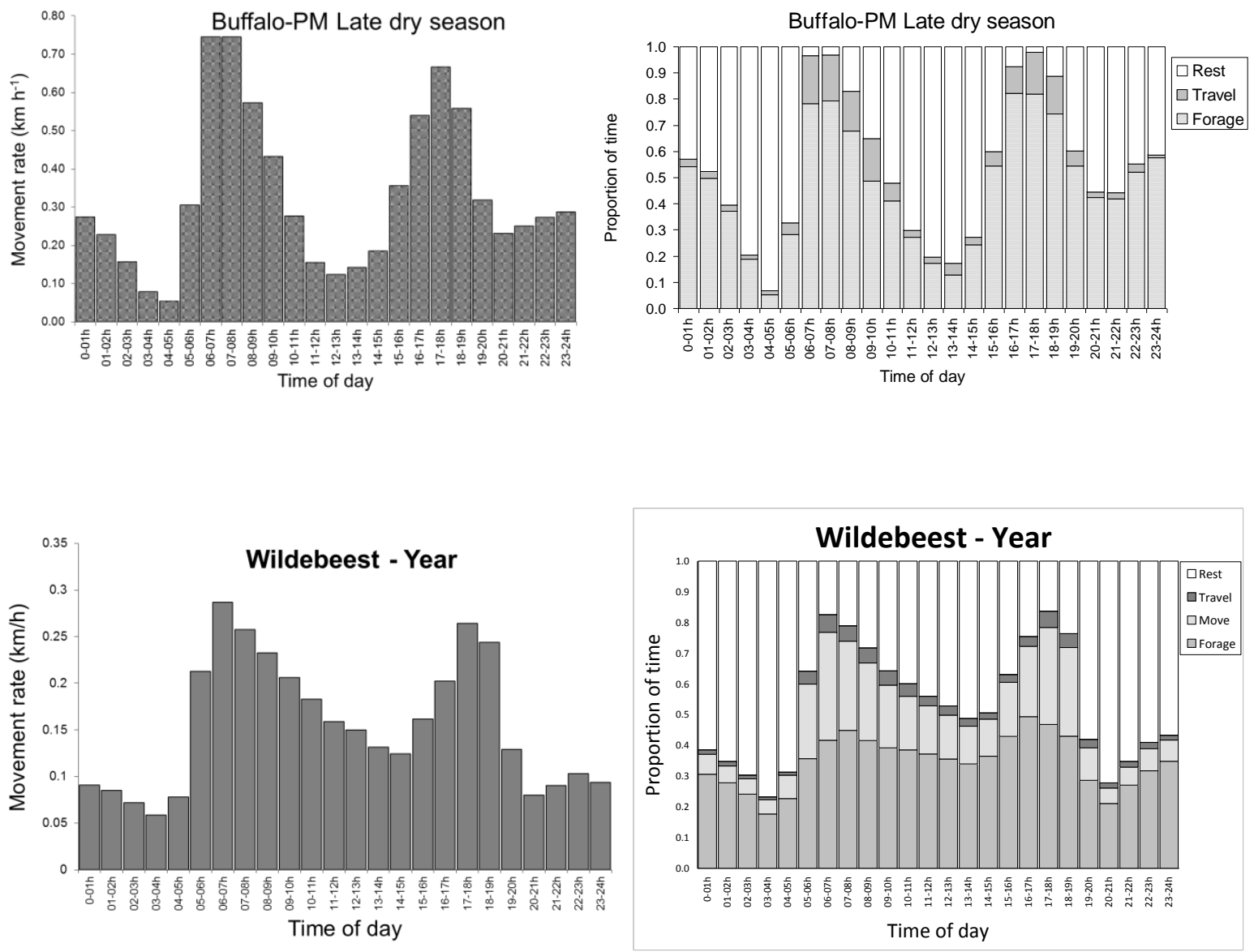